\title{
PEDAGOGICAL SUPPORT OF FUTURE TEACHER'S PROFESSIONAL DEVELOPMENT IN UKRAINE
}

\section{ПЕДАГОГІЧНА ПІДТРИМКА ПРОФЕСІЙНОГО РОЗВИТКУ МАЙБУТНІХ УЧИТЕЛІВ В УКРАЇНІ}

2019-17-2-10

\section{Palaguta I.V.,}

Lecturer at the Department

of Foreign Languages

Pavlo Tychyna Uman State

Pedagogical University

\begin{abstract}
In the article the basic problems of the pedagogical support of future teacher's professional development in Ukraine are analyzed. Basic approaches to the determination of the concept "pedagogical support" are presented. General principles, which are connected with the pedagogical support are reflected and described: cooperation, which lies in the interaction of individuals, who get a pedagogical support; development, which involves taking into consideration future teachers' desires and needs to self-knowledge and self-expression; natural compliance, according to which pedagogical support should be based on the general laws of the development of a human nature; subjectivity, according to which the teacher contributes to the development of the future teachers' ability to realize themselves as personalities in relations with other people and the environment; recognition of future teachers' value at the moment of their development, maintaining respect to them, regardless of their success, the development of characteristic features, abilities.

The following requirements for the future teachers'pedagogical support in the process of learning are presented: participation of the whole teaching staff in the organization of pedagogical support; ensuring the conditions for future teachers to realize their opportunities, creation of a favorable moral and psychological climate in the group; implementation of a democratic style of communication; the ability of teachers to notice and appreciate the unique individuality of each future teacher and conduct pedagogical diagnostics. All-Ukrainian monitoring research, which was devoted to the pedagogical support, which future teachers received from qualified teachers (according to the TALIS methodology) was characterized.

Key words: professional development, pedagogical support, future teachers, qualified teachers, self-realization, self-education.
\end{abstract}

Описано основні принципи, які лежать в основі педагогічної підтримки: співробітництва, що полягає у взаємодії суб'єктів педагогічної підтримки; розвитку, який передбачає врахування прагнення й потреби майбутнього вчителя до самопізнання, самовираження; природовідповідності, за яким педагогічна підтримка має ґрунтуватися на загальних законах розвитку природи людини, розвивати в неї відповідальність за саму себе; визнання цінності особистості на цей момент їі розвитку, збереження поваги до неї незалежно від ії успіхів, розвитку характерних особливостей, здібностей.

Представлено певні вимоги до здійснення педагогічної підтримки майбутніх учителів у прочесі навчання: участь усього педагогічного колективу в організації педагогічної підтримки; забезпечення умов для реалізації майбутніми вчителями своїх можливостей, де стосунки між ними і педагогами будуються на основі співпраці, взаєморозуміння, повазі інтересів і прав кожного учасника освітнього прочесу; впровадження демократичного стилю спілкування, свободи творчих дискусій, обміну думками, культури спілкування; уміння педагогів помічати й цінувати неповторну індивідуальність кожного майбутнього вчителя та проводити педагогічну діагностику; педагог, який працює в умовах педагогічної підтримки, має пам'ятати ще про один аспект - це дозованість педагогічної підтримки; конфріденційність у роботі з кожним майбутнім учителем; віра в кожного майбутнього учителя та його можливості; важливою вимогою успішності педагогічної підтримки $\epsilon$ очінювання навчальної діяльності майбутніх учителів.

Охарактеризовано Всеукраїнське моніторингове дослідження, яке присвячене педагогічній підтримці, яку отримують майбутні учителі від кваліфікованих вчителів (за методологією TALIS).

У статті проаналізовано основні проблеми педагогічної підтримки професійного розвитку майбутніх учителів в Україні. Представлено основні підходи до визначення терміна «педагогічна підтримка».
Ключові слова: професійний розвиток, педагогічна підтримка, майбутні учителі, кваліфріковані вчителі, самореалізація, самоосвіma.
Problem statement in general. Modern European educational society shows a great interest in the policy of supporting future teacher's professional development. Exactly the period of teacher's professional development is recognized as the most stressful, because it is associated with the transition to a new system of social relations. Difficulties of young teacher's professional adaptation are largely determined by the difference of knowledge obtained in educational establishments, the real context of the school, the typical teaching environment.

The future teacher's professional development is not only influenced by professors and a teaching staff, but also by the process of future teacher's self-edu- cation. In the process of future teacher's professional development, a qualified teacher should support a young teacher, because a future teacher doesn't have an experience, the knowledge of human nature, skills of self-organization and self-regulation [1].

Analysis of recent research and publications. In scientific researches devoted to questions of the pedagogical support of future teacher's personality, pedagogical support is considered as a providing assistance in solving problems of the individual's development (A. Andreev, T. Anokhin, O. Gazman); as interaction, friendly relations, internal adjustment on the common positive result of the teacher and a subject of learning (N. Krylov, N. Mikhailova); 
as a pedagogical activity that provides processes of a personality individualization (V. Berdekhanova, G. Soroka); as an active complicity in the life of a person's self-identification, preparation for a choice in problem situations, self-realization and elimination of subjective obstacles to development (G. Kostiuk, V. Rybalka).

The analysis of pedagogical sources has shown that the process of studying at higher educational establishments , conditions of a person's pedagogical support require consideration of certain normative requirements:

- a compliance with public needs aimed at the main goal of higher educational establishments of Ukraine in modern conditions - the formation of a teacher capable to solve the problems of the educational process at school, creatively providing intellectual, physical, moral development of students, that is, preparing a highly educated and a highly skilled specialist;

- providing good relations between qualified teachers and future teachers, so that in the pedagogical process not only a future teacher develops, but also the teacher improves his scientific and theoretical, methodological level;

- a relationship of a purpose, tasks, content, methods and forms of a training organization, which is based on interdisciplinary psychological and pedagogical integration [4].

The purpose of the article. The purpose of the article is to show and characterize the pedagogical support of future teacher's professional development in Ukraine.

Presenting main material. In psychological and pedagogical literature, there is no a single approach to the definition of a "pedagogical support"; it is considered as a special sphere of a pedagogical activity, aimed at helping to develop and promote future teachers' self-development, in solving their individual problems related to advancement in education, developing the need for the success of independent actions; systematic and purposeful activity of a teacher (or a team of teachers), which ensures the disclosure of the future teacher's potential by providing specific assistance in solving the difficulties of studying and promoting self-determination and self-actualization of a person as a specialist; assisting the student in overcoming obstacles, difficulties, relying on a future teacher's subjective experience and means for identifying and solving his problems [2, p. 99-101].

All above-mentioned and the analysis of a pedagogical literature give a background to consider a pedagogical support as a specially organized interaction of individual's cognitive activity, which is modeled for future teachers' active learning of the social experience accumulated by the humanity in various branches of science in order to develop intellectual, sensually volitional and other spheres of their life, self-education and self-realization [4].
Today, principles of pedagogical support are the subject of teachers' and psychologists' comprehension in Ukraine. Principles of a pedagogical support is a complex of basic ideas underlying the position of the teacher in relation to the future teacher's personality.

Researchers consider the following principles of a pedagogical support: complexity, mediation, individualization of assistance; the necessity for systematic and active approaches that involve the choice of means and ways, goal setting and activity display; responsibility, confidentiality; cooperation, development, subjectity; obligatory love in education, mutual openness, deep communication.

Sharing the thoughts of N. Andryushchenko, O. Kodyatenko, we believe that pedagogical support should comply with the following general principles:

- cooperation, which lies in the interaction of individuals, who get a pedagogical support;

- development, which involves taking into consideration future teachers' desires and needs to selfknowledge and self-expression;

- natural compliance, according to which pedagogical support should be based on the general laws of the development of a human nature;

- subjectivity, according to which the teacher contributes to the development of the future teachers' ability to realize themselves as personalities in relations with other people and the environment, to reflect future teachers' actions, to predict their consequences for themselves and for others, to evaluate their choice;

- recognition of future teachers' value at the moment of their development, maintaining respect for them, regardless of their success, the development of characteristic features, abilities.

Investigating the problem of future teachers' pedagogical support, O. Gazman mentioned a certain system of rules:

- an individual can not be a mean of achieving pedagogical goals;

- a teacher must accept an individual, because everybody has constant changes and constant development;

- all difficulties in the behavior of the individual overcome with the help of moral means;

- do not humiliate the dignity of your personality and personality of the future teacher;

- trusting - do not check;

- the teacher must recognize the right of a young person to a mistake and do not condemn for it;

- the teacher must be able to recognize his mistake in time [2].

On the basis of the analysis of psychological and pedagogical literature on the problems of the pedagogical support and the organization of the educational process in higher educational establishments, we can outline the following requirements for the 
future teachers' pedagogical support in the process of learning:

1. Participation of the whole teaching staff in the organization of pedagogical support. The necessity to comply with such a requirement is due to the fact that when determining the level of the future teachers' development, each teacher has his own opinion, as students in different ways relate to each discipline, and therefore when determining the level of the future teachers'development, all teachers points of view of should be taken into consideration.

2. Ensuring the conditions for future teachers to realize their opportunities, where relations between them and teachers are built on the basis of cooperation, mutual understanding, respect for the interests and rights of each participant in the educational process.

3. Creation of a favorable moral and psychological climate in the group affects the emotional relaxation of the individual in an atmosphere that is determined by the feelings of future teachers, a sense of comfort from staying in the group, facilitating relationships in it.

4. Implementation of a democratic style of communication, freedom of creative discussions, exchange of ideas, culture of communication. Compliance with this requirement is due to the fact that the influence of the teacher on the personality of the future teacher is carried out through direct communication with him.

5. The ability of teachers to notice and appreciate the unique individuality of each future teacher and conduct pedagogical diagnostics. The effectiveness of the pedagogical support depends on the teacher's ability to conduct a pedagogical diagnosis, which is the instalation of the level of the future teachers development. The purpose of the diagnostics in the conditions of the pedagogical support is the observation of qualitative changes occurring in the future teacher; analysis of a collected information to identify changes, both positive and negative, in development, in the professional development of the future teacher's personality, etc.

6. A teacher who works in a pedagogical support should remember about one more aspect - the dosage of pedagogical support. It should be noted that timely received pedagogical support frees a young person from the majority of unsolved problems associated with self-realization of the person who accumulate and prevent people from being themselves, studying and developing.

7. Confidentiality in working with each future teacher. The result of this requirement is setting up a trusting relationship between all participants in the pedagogical process.

8. Belief in every future teacher and his opportunities; the evaluation is not a person, but his actions and reasons that cause them; to help each young teacher in revealing himself, in the formation of a person, preserving its uniqueness.
9. An important requirement for the success of the pedagogical support is the evaluation of the educational activities of future teachers. In the conditions of the pedagogical support in evaluation future teachers, qualified teachers does not evaluate the work of the future teacher, but the activity in accordance with the individual capabilities of each individual.

So, we can say that the pedagogical support is not only a pedagogical activity aimed at a self-realization of the future teacher's personality, but also the valuable attitude of the qualified teacher to the personality of each future teacher; respect for his individual identity; the perception of the future teacher as an equal, as the subject of the educational activity and his own life, which is not similar to others, the inner world, caring for the future teacher's psychological comfort.

In order to identify the real situation in Ukraine, All-Ukrainian monitoring research was conducted on teaching and learning among headmasters and teachers of secondary schools (according to the TALIS methodology). One of the parts of this research was devoted precisely to the issue of pedagogical support, which future teachers received from qualified teachers.

In the All-Ukrainian monitoring research of teachers, a special part is exuded, which is also called "Professional Development and Support of Teachers". In this special part, "professional development" is defined as a series of events aimed at developing individual skills, knowledge, qualifications and other characteristics of teachers with the ultimate purpose of improving their pedagogical practice [3, p. 86].

Pedagogical support for young teachers during their entry into their professional activity is a transitional stage from university to work at school, information on various activities contributing to their socialization was collected.

The main focus of TALIS was on the following professional development activities:

- courses / trainings (for example, on the subject or teaching methodology and / or other pedagogical problems);

- pedagogical conferences and seminars (in which teachers and / or researchers present their researches and discuss pedagogical problems);

- exploratory / inspection visits to other schools;

- exploratory inspection / visits to enterprises, public and non-governmental organizations;

- training courses during the main work at enterprises, institutions, public and non-governmental organizations;

- participation in professional associations created for the purpose of teachers' professional development;

- work on an individual or collective research project on a professionally oriented subject;

- mentoring and / or mutual assistance by colleagues as part of an official school practice. 
TALIS asked teachers about participation in abovementioned activities during the last 12 months before the interrogation and their impact on a teaching practice. It was also about the support (financial or nonfinancial) that teachers received for the implementation of these activities, the necessity for professional development in various aspects of a school life and obstacles to the professional development [3, p. 86].

According to the young teachers' availability and access to mentoring programs, we can point out that mentoring in TALIS is defined as a school structure of support and counseling by experienced teachers of less experienced teachers, young teachers. This structure can cover all teachers in the school or just young teachers. Recently, in many countries, mentoring programs have become the dominant form of teacher's professional socialization. All of them mentioned the direction of the young teachers' development, but the character and content of such programs varies widely.

Thus, according to TALIS research, in Ukraine, almost half (47.1\%) of teachers work at schools, where headmasters mentioned that mentoring programs were available only for young teachers who started their teaching activities. At the same time, teachers who started working at this school (19.3\%) and all school teachers (22.8\%) have access to mentoring programs lower than the average international level.

In Ukraine, the majority of teachers (90.7\%) work at schools, where headmasters pointed out that the subject, which taught by the mentor, in most cases, is the same direction as the subject of a teacher who started a professional activity. $25.8 \%$ of Ukrainian teachers were mentors of one or more teachers. $15.9 \%$ of Ukrainian teachers had an appointed mentor. Significantly, more women $(27.2 \%)$ than men (18.4\%) among teachers who are mentors for one or more teachers. At the international level, there is no a significant difference in gender between the two categories. It is natural that teachers with experience more than 5 years are worked as mentors (28.7\%) than those who have appointed a mentor (10.0\%). In Ukraine, $62.1 \%$ of teachers with a work experience of 5 or less years have an appointed mentor (average level of TALIS 24.8\%). Similarly, teachers with a permanent employment are more often mentors (26.4\%) than those who have an appointed mentor (15.1\%) [3, p. 87-91].

So, we can come to the conclusion, although at the theoretical level: the problem of the pedagogical support for both future and qualified teachers in Ukraine has been developed quite seriously, with the attention on the forms of the pedagogical support, on the peculiarities of this support, on the importance of this support in a career growth of a young specialist. We can confirm that at the practical level, the imple- mentation of various forms of pedagogical support in Ukraine is still not at the proper level.

Therefore, first of all, we would like to pay your attention to some aspects of the young teachers' pedagogical support. In addition to receiving the pedagogical support at the university and at school, future specialists must attend various events that promote their socialization (courses, various activities and seminars, visits to other schools, participation in professional associations created for the purpose of professional development of teachers, etc.).

During the courses, it is important to put in the program a module that will help professionals to provide mentoring to young teachers.

Conclusions. The system of a university tutoring must be institutionalized - tutoring must become a real, not a nominal aspect of a university life. That is, it should be not only the work of informing the academic group about the activities that will take place at the university at one time or another, working with students who do not have time to attend classes, and this should be an individual work, because tutoring involves work from 1 to 3-4 students. The work must be carried out according to a certain plan, based on real researches and knowledge of the future teachers' individual characteristics, and also should end with the development of a professional development program, that is, a professional program of a the university's graduate. This work can also be carried out at the level of the magistracy, that is graduate of the master degree in the specialty "Teacher of a higher educational establishment", where they should teach tutoring, that is, to give a future teacher an opportunity to conduct a tutorial activity. Such tutorial activity should be aimed at providing teaching support and training at any higher educational establishment at the place of a work.

\section{REFERENCES:}

1. Palahuta, I. (2016). Pedahohichna pidtrymka profesiinoho samopiznannia maibutnikh uchyteliv $u$ ikhnii fakhovii pidhotovtsi. Problemy pidhotovky suchasnoho vchytelia : materialy zbirnyka naukovykh prats Umanskoho derzhavnoho pedahohichnoho universytetu. S. 364-369.

2. Hazman, O. (1995). Pedahohycheskaya podderzhka detey $v$ obrazovanyy kak ynnovatsyonnaya problema. Ynnovator, $58 \mathrm{~s}$.

3. Shudlo, S., Zabolotna, O., Lisova, T. (2018) Ukrainski vchyteli ta navchalne seredovyshche. Za rezuItatamy Vseukrainskoho monitorynhovoho opytuvannia vykladannia ta navchannia sered dyrektoriv i vchyteliv zahalnoosvitnikh navchalnykh zakladiv (za metodolohiieiu TALIS). Drohobych : TzOV «Trek-LTD», $300 \mathrm{~s}$.

4. Anderton, L. Re-Designing the Personal Tutoring System. Self Initiated Project. Louise Anderton, 2000. 